\title{
Working by projects: A way to enrich critical thinking and the writing process in a third grade EFL classroom
}

\author{
Trabajo por proyectos: pensamiento crítico y proceso \\ escritural en inglés en un salón de tercero de primaria
}

\author{
Sandra Dolores Ruiz Niño \\ Colegio José María Carbonell \\ carirasa@yahoo.com
}

Received 21-Jul-2013/Accepted: 27-Nov-2013

\begin{abstract}
This document presents the result of a qualitative action research developed with thirty-three third grade students at a public school in Bogota. This action research aimed at describing and analyzing the role of project work in the development of critical thinking in third grade EFL students and to describe and document the way in which those students developed their writing skills through this methodology. The participants developed different inquiries related to topics they were interested in exploring and related to the recycling project of the school. The data were collected during eleven sessions carried out along eight months through field notes, artifacts, and audio recordings. The results show that through project work the students enhanced their emerging critical thinking skills and their writing process; improved their interactions with their classmates, discovered that learning English was something useful for their lives, and therefore they acquired more confidence in writing and speaking in English. Additionally, they became more reflective, organized and critical about what they think, what they say, and about what happens around them.
\end{abstract}

Key words: Critical thinking, Project work, writing skills.

\section{Resumen}

Este documento presenta el resultado de una investigación-acción cualitativa desarrollada con treinta y tres estudiantes de grado tercero de un colegio público de Bogotá. Esta investigación-acción tuvo como objetivo describir, analizar y documentar el papel del trabajo por proyectos en el desarrollo del pensamiento crítico en los estudiantes de inglés como lengua extranjera del grado tercero; y la manera a través de la cual dichos estudiantes desarrollaron sus habilidades en escritura a través de esta metodología. Los participantes llevaron a cabo diferentes investigaciones relacionadas con temas de su interés en torno al proyecto de reciclaje del colegio. Los datos fueron recolectados durante once sesiones a lo largo ocho meses a través de notas de campo, producciones escritas de los estudiantes y grabaciones de audio. Los resultados mostraron que a través del trabajo por proyectos los estudiantes cualificaron sus habilidades de pensamiento crítico emergentes y su proceso de escritura, mejoraron las interacciones con sus compañeros de clase, descubrieron que el aprendizaje de inglés era algo útil para sus vidas y por consiguiente, adquirieron más confianza para hablar y escribir en inglés. Además, las participaciones se hicieron más reflexivas, organizadas y críticas en relación con lo que piensan, lo que dicen y lo que sucede a su alrededor.

Palabras clave: Pensamiento crítico, Trabajo por proyectos, Habilidades de escritura.

Résumé

Ce document présente le résultat d'une recherche action-qualitative déroulée avec un groupe de trente et trois élèves de CE2 au sein d`une école publique à Bogota. L`objectif de cette recherche-action a été de décrire, analyser et documenter le travail par projets dans le développement de la pensée critique chez les élèves de CE2 et leur processus de production écrite en anglais. Les participants ont développé différentes recherches liées à leur sujet d'intérêt autour du projet de recyclage de l'école. Les données ont été recueillies pendant huit mois et en onze sessions au travers le journal de bord, les productions écrites des élèves et les enregistrements audio. Les résultats ont montré que grâce au travail par projets, les élèves ont amélioré leurs habilités dans la pensée critique initiale ainsi que dans leur processus drécriture. Ils ont aussi amélioré leurs interactions avec la classe, ils ont découvert que l,apprentissage de lıanglais était utile pour leur vies, ainsi que 
la confiance acquise pour parler et écrire en anglais. En plus, les élèves ont démontré plus de réflexion, d`organisation et drargumentation critique par rapport à leurs pensées, leurs mots et ce qui les entoure.

Mots clés: Pensée critique, Travail par projets, Habilités d'écriture.

\section{Introduction}

The purpose of this document is to present the results of a research study related to working by projects and critical thinking in third grade EFL students, as a methodological strategy that can improve the learning environments. Due to the fact that education evolves day by day, it is necessary to include and develop dynamic methodologies which allow the new generation of students to have a more participative role based on cooperative and collaborative work. In this way, it is possible to help students develop new learning strategies and skills to acquire and produce knowledge. Working by Projects in the school context can be seen as a valuable opportunity through which students can derive their learning from significant experiences, interests, and questions related to the environment in which each one of them is immersed.

It could be a useful tool through which they answer those questions, taking into account that each student has a different style and particular form of thinking, seeing and comprehending the world. For this reason, the aim of this article is to describe and analyze what critical thinking skills are evidenced when project work is implemented and what the role of project work in the development of writing skills in third grade EFL learners is.

This document includes a general description about the type of study, research approach, setting, participants, and sampling, the data analysis process, the findings and the discussion of these findings, and conclusions of the study.

\section{literature review}

\section{Project Work}

Throughout my experience as a third grade English teacher, I have seen that the traditional methodology based on memorization of contents and grammar rules neither promotes enough interest and autonomy in the students nor develops their critical thinking skills to assume their foreign language learning processes in a dynamic and interesting way. This lack of critical thinking skills poses the issue that the EFL classroom needs a methodology that should be more dynamic, more centered on the students' interests and their world and at the same time, useful to promote foreign language learning.

Cuspoca (2002) defines project work as:

Set of teaching strategies that includes multiskill activities, ideas and resources, which allows teachers to guide students through an in-depth investigation of a real world topic worthy of children's attention and efforts because it tries to solve one of their problems or any other of their daily activities that require a previous plan. (p. 28)

The activities should be planned purposefully and carefully as the author proposes taking into account students' needs, likes and expectations in order to guide them into a project.

An important aspect regarding project work is considered by Harris and Katz (2010), who carried out a study related to working by projects. They established the possibility of promoting parents' participation in the children's learning process. In my study this aspect was also very important. Some students' parents attended the final presentation of the project, and through this activity they could see how the project was developed and how it motivated their children to improve their English learning process. In other words, they could see the learning of English as something useful in their lives, and not only as another subject. 
On the other hand, Harris and Katz (2010) add:

Projects also encourage children to write. They attempt to write because they have a purpose for writing: to communicate across time, and with others. They write a question in order to remember it, they write words on pictures and label the parts of things...writing becomes important to them because they see writing as a tool for their investigation (p.104)
For these reasons, I considered that project work could be a way not only to promote knowledge and group work, but also to enhance the writing process in the EFL classroom.

Additionally, Fillmore (cited in Harris \& Katz, 2010) suggests including in the projects some strategies for children who are learning English. I used some of these strategies in the development of my lessons. The strategies suggested are the following:
1. Use demonstration

2. Model and role play

4. Repeat words, sentence patterns, and routine

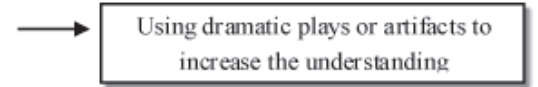

Including role playing and dramatic environments to provide language practice

Discussing what students know about the topic, using graphic organizers and lists to connect new words and students' experiences

Using sentences that students understand along the project. Including songs, poems and thymes to provide repetition

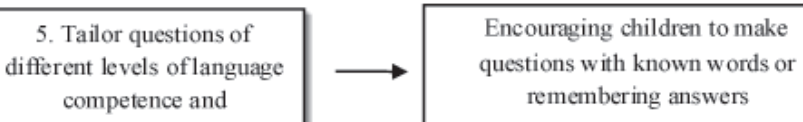

Figure 1. Strategies for children who are learning English

Another author who provides a different definition of project work is Stoller (cited in Richards \& Renandya, 2002). She defines project work as:

A versatile vehicle for fully integrated language and content learning, making it a viable option for language educators working in a variety of instructional settings, including general English, English for academic purposes (EAP) English, for specific purposes (ESP), and English for occupational/ vocational/professional purposes, in addition to preservice and in-service teacher learning (p.109).

In this sense, learning a foreign language through working by projects can be more meaningful than working with a traditional methodology, since developing a project can be seen as a way through which students can integrate language and content 
learning, interact, think, reflect, and construct knowledge from significant and real experiences.

What is interesting in the work developed by Stoller is that she establishes ten stages through which teachers and students can develop meaningful projects that facilitate content learning and provide opportunities for explicit language instruction. Those steps are:

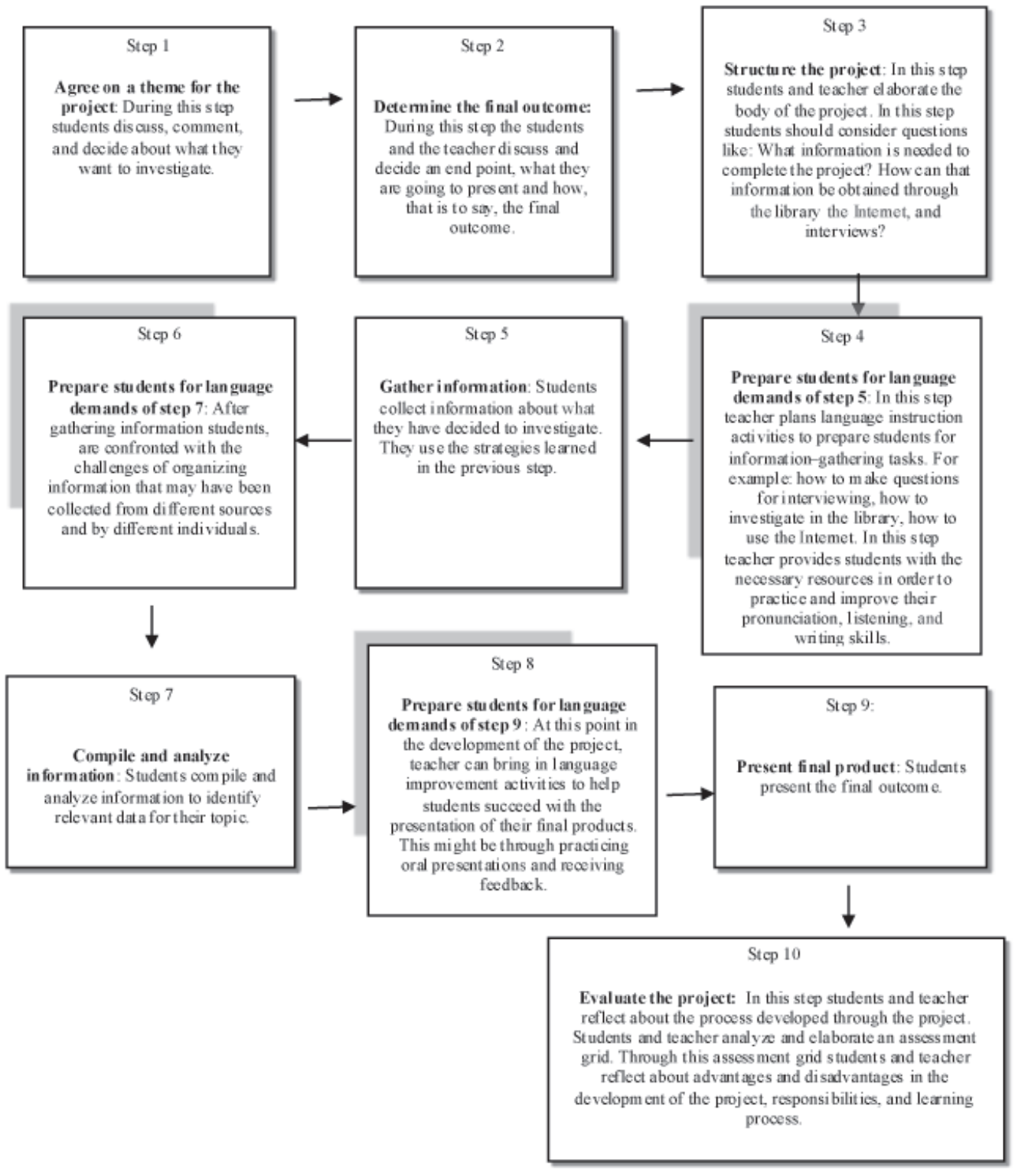

Figure 2. Stages in project work. Note: Adapted from: Project Work: A means to promote language and content (Stoller, 2000) 


\section{Critical thinking}

There are many definitions for critical thinking. I will include some of them here which allow us to have different perspectives on this concept: Giroux's (cited in Davis-Seaver \& Davis, 2000) sociopolitical view, Moore and Stanley's (2009) vision of critical thinking as a process for reflecting about the world and Paul E Elder's (2005) consideration that it bears wonderful potential to produce and analyze information. Finally, I will include Bloom's (1990) revised taxonomy.

For Giroux (1992), critical thinking is a political act which holds the key to the continuance of democracy and an open society. This act implies teaching the students to think and reflect for themselves and to gain a better understanding of reality, truth, and knowledge through critical thinking. The betterment of understanding must be used for the benefit of others and to bring about a more democratic and just society (cited in Davis-Seaver \& Davis, 2000)

For Moore and Stanley (2009), critical thinking is a process through which the students are able to think and reflect about the world for themselves. These authors establish that critical thinking requires not only understanding about when things have happened or who did something, but also being able to explain why and how it has affected the world or our history. In addition, they explain that only when students have understood the first three lower levels of Bloom's taxonomy - knowing/remembering, understanding and applying, can they accomplish analyzing, evaluating and creating. That implies that we as teachers need to know how to ask and assess at the different levels in order to promote and enhance higher critical thinking levels.

Moreover, Paul \& Elder (2005) consider critical thinking "as a process by which the thinker improves the quality of his or her thinking by skillfully taking charge of structures inherent in thinking and imposing intellectual standards upon them" (p.1). This means that children have a wonderful potential to produce and analyze information, but it is necessary to implement the adequate strategies to engage them in the thinking and learning process.

The concept of critical thinking is not new; it has been studied for a long time. In 1956, Benjamin Bloom headed a group of educational psychologists who developed a classification of levels of intellectual behavior important in learning. Bloom found that over $95 \%$ of the test questions students encountered required them to think only at the lowest possible level related to the recall of information. Bloom identified six levels within the cognitive domain; ranging from the simple recall or recognition of facts; at the lowest level, through increasingly more complex and abstract mental levels, to the highest order which is classified as evaluation.

During the 1990's a new group of cognitive psychologists, led by Lorin Anderson (a former student of Bloom's), updated the taxonomy reflecting relevance to 21 st century work. In the new version, verbs instead of nouns describe the different levels of the taxonomy.

The objective of changing the nouns to verbs is to mean continuity of thought, that is, its constant activity in each category. The revision of Bloom's taxonomy implies meaningful changes in three aspects: terminology, structure and emphasis. The taxonomy reflects different forms of thinking using active verbs that more accurately reflect the active nature of thinking. Another aspect was to consider the process of synthesis with a broader view and relate it to creating (assuming that all synthesis is in itself a creation).

The sequence in which different categories are presented was also modified swapping their order, and writing -"evaluating and creating-" instead of -"synthesis and evaluation". Finally, the revised version of the taxonomy is intended for a much broader audience. The emphasis is placed upon its use as a more authentic tool for curriculum planning, instructional delivery and assessment. Besides, it is easily applied to all levels of schooling. 
In this study the concept of critical thinking in the school context is based on Bloom's revised taxonomy. It can be seen as a valuable opportunity through which students make connections between their background knowledge and the environment that surrounds them. Therefore, students will not be viewed as passive recipients of knowledge but as active members of a society.

I think that developing critical thinking through student-centered activities promotes participation and interest in their own learning process, and this contributes to enriching and qualifying the EFL classroom. In this sense Martinez (2007) suggests: "Life can be described as a sequence of problems that each individual must solve and critical thinking skills are problem solving skills that result in reliable knowledge" (p.31). I agree with her in the sense that it is important to develop higher order thinking skills; it is necessary that students be capable of thinking "divergently and creatively;" on the other hand, teachers must provide more opportunities in the EFL classroom where students can participate, discuss, create, and of course, learn English as a tool to construct meaning and understand the world.

\section{Writing process}

Writing is an act that involves a clear understanding about what we want to say. In today's society, the act of writing is immersed in every aspect of our lives. The ability to write properly gives one the power and opportunity to share thoughts, ideas, and opinions with others. Moreover, the ability to write correctly allows one to influence the present and the future through one's ideas. Writing is a process which requires the development of some sub processes in order to express our thoughts correctly. According to Silva (1993), these sub processes are planning, transcribing, and reviewing. The first sub process consists of reflecting or thinking about what the writer wants to write or express, the second one has to do with the act of writing, and the last one is related to the activity of revising and writing again.
For other authors like White and Arndt (1991), the writing process can be summarized through the following steps: brain-storming, planning, writing the first draft, editing, proof reading, final product, and publishing. The same author establishes these ways of giving feedback: teacher editing, peer-editing, and self-editing.

There is no doubt about the pertinence and great impact that projects have on the educational context where they have been carried out, especially in relation to EFL learning. Dresden and Lee (2007), who developed a study called "The effects of project work in a first-grade classroom: A little goes a long way," established that through project work students could easily develop the writing skill. According to these authors, project work provides the children with valuable opportunities for writing about what they are interested in and at the same time, children develop more reflection and consciousness about what they want to write, different from some perspectives through which the students learn to write only by repeating words, sounds or letters without any sense. Besides, students were able to relate their lives to the writing process; in other words, they were able to articulate what they wanted to investigate through the development of questions and answers using the writing skill.

In fact, writing is an activity that people develop throughout their lives. In this respect, Murray (2003) argues that writing is an unfinished process that requires us to consider that in our classrooms, students and teachers work with language in action. That is to say, we are looking for the correct word, negotiating meanings of sentences for expressing our thoughts and communicating with others constantly. I think that it is necessary to think that learning to write is a complex process through which we can express our thoughts and feelings, at the same time that we establish communication and relationships with others. For this reason, it is vital to modify our methodological perspectives and change the curriculum composition because the writing process 
requires time, practice, support, and knowledge of our students.
For Murray the writing process can be basically divided into three stages, which are explained in the following figure:

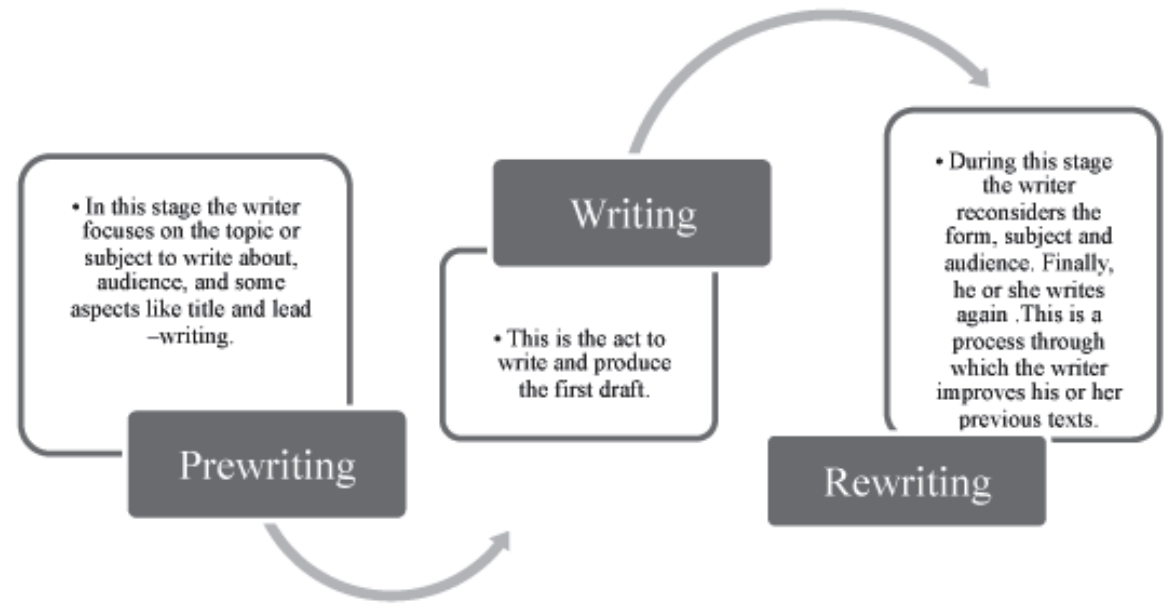

Figure 3. Stages in writing process. Note: Taken from Teach writing as a process not product (2003). Retrieved from http://www.willamette.edu/gse/owp/docs/TeachWritingasaProcessNotProduct.pdf

In this sense, writing involves motivation and personal interest from the writer. Likewise, for Ramirez (2007), this act demands communication between unknown and distant partners, who interact through words which can be retrieved in new communication act. Far from those methodologies that rely on repetition and transcriptions, writing is a careful process which involves different steps aimed at reflecting upon our thinking and reality. In this sense, Rinnert and Kobayashi (2009) highlight that:

The writing of EFL students is affected not only by their first language (L1), but also by the educational context where they learn to write. This socially and culturally characterized context provides metaknowledge about writing (i.e. view of audience and goals of writing), as well as linguistic and textual knowledge, affecting the ways in which students process and produce writing (p.23).

This requires providing the classroom and the school context with more opportunities for writing and developing meaningful experiences. Through my practice as a primary school teacher, I have noticed that students learn more if their interest and enthusiasm are awaken, and if they are allowed to connect their knowledge in both languages and their life experiences to their school practice.

In this respect, Baynham (1995) claims that one of the most important tasks of the teachers is to provide the classroom with enough opportunities to trigger learning. Those opportunities should promote the interactions of the students and their active participation through the writing activities. Additionally, this process should be accompanied by the continuous revision of the teacher, who should give enough feedback during the drafting and redrafting processes. Regarding the different interactions given during the writing process Hyland (2009) establishes that writing is a social act that implies recognizing that one writes to keeping in mind the context, a specific purpose, and a specific reader.

Finally, this socio-cultural view of writing is supported by Ruiz (2003), who developed a research 
process called "Kidwatching and the development of children as writers", with second grade students in a private school in Bogota. She remarks that:

New perspectives that perceive writing as a dynamic process involving thought, language, and interaction need to be implemented by teachers in their classrooms. These new perspectives consider the connections that exist between reading and writing, as well as the connections that should exist between students' home and school experiences (p.52).

Based on this study, it is necessary to change our minds as foreign language teachers about the meaning of the writing process, especially in public school contexts in which students have less time to devote to the English class.

From that point of view, Lillis (2001) argues that the context of culture in which students are immersed contributes significantly to meaning making. In this sense, this universe of culture includes the different voices that students bring with them during the act of writing. Therefore, it is relevant to provide the English class with enough opportunities for writing about the students' beliefs, their knowledge about the world, and different aspects related to their interests, likes, and necessities.

\section{Methodology}

As a teacher researcher my role in this study was that of an observer and participant. My role was very active and reflective, taking into account that this was a qualitative research that included action research as a way to observe, analyze, describe, act, and reflect about what was happening in the classroom and my role as a foreign language teacher.

This research proposal was developed with the third grade students of a public school in Bogota. The school is located in the fourth zone, San Cristobal, and the students and their families belong to social strata 1 and 2. The school offers grades from preschool to eleventh grade with a commercial emphasis.
The students' families work mainly in construction, recycling, security, cleaning, and other informal activities. Regarding the vision and mission, the school aims at training students who may be linked to field work in relation to commercial subjects and at the same time, improve their living conditions in the social, personal, and family fields. In this sense, the school has an agreement with Servicio Nacional de Aprendizaje (SENA), and the recognition obtained through it is that of a commercial high school.

During this study I implemented the action research cycle based on Burn's (2003) theory. The whole cycle was repeated twice: planning, acting, observing and reflecting. I asked students about the recycling project and I started to follow the steps of project work. Then, I realized students needed more help with language learning so I implemented new and different activities for helping students' with their language needs.

The project was developed following the steps suggested by Stoller (2000). First, the third grade students were divided in groups and each group chose a topic related to environmental care, taking into account that this aspect is the main goal of the recycling project of the school. After this, each group researched about the topic selected: animal care, water care, how to elaborate recycled paper, and plant care. Then, and after several drafts each group created a mini book, poster or frieze related to the topic chosen. Finally, each group shared their findings and creations with the other students of the school and their parents.

\section{Participants and Sampling}

The 302 class with which the research was developed included thirty- six boys and girls, who were between eight and eleven years old. I selected the 302 grade as sampling to comply with one of the types of Purposeful Sampling explained by Merriam (1998). She states that convenience sampling is based on issues of time, money, location, availability of sites or respondents; therefore, I chose this class 
taking into account that I spent more time with them than with the other classes, because I was their tutor. For these reasons, the research process could be better observed, analyzed, and described, which might contribute positively to enrich and clarify some of the interactions, attitudes, and phenomena that occurred in the context.

The process to collect the data was developed from February to September of 2011. In order to implement and develop the research in the third grade I used one consent form for the institution, one for the students' parents or guardians and one for the students. Through these documents the school community was informed about the research and the different activities that were going to be developed.

\section{Data Collection Instruments and Procedures}

In order to collect data in this research I used different instruments as defined by Burns (2003). These instruments will be described and characterized in terms of their advantages in this research process.

Audio Recordings. Burns (2003) describes as audio or video recordings the instruments "providing objective records of classroom interactions" (p.79). Through the data collected from this instrument it was possible to contrast the students' interactions with the information gathered through the other instruments. This instrument also provided objective records during the analysis which avoided the influence of personal beliefs or misinterpretations, and it allowed me to collect objective information about what students were doing during the sessions.

Field notes. As Patton (2002) claims, one of the main objectives of observation of a data collection instrument is to describe the setting where the phenomenon takes place and the participants in interaction.

Additionally, Wallace (2006) argues:

Field notes can be in the form of a record of work, recording basic information, besides information that can be useful for later reflection for example: general instant self- evaluation, focus on a particular aspect of teaching and learning, for example: the functioning of group work, the performance of an individual student. (p.58)

This instrument allowed me to analyze the students' interactions during group work, and it provided descriptions of the students' writing process and their interactions that could be useful during the data analysis.

Artifacts. These are student's documents or productions that allow observation of different characteristics and specific details of a process observed. Merriam (1998) argues that "document" is a term used to define all written, visual, or physical material which may be useful to enrich the study being developed. Additionally, she mentions different types of documents such as public records, personal documents or physical material; all of them can provide the researcher with particular information to enrich the study. This instrument allowed me to see how the students wrote along the development of the project and how they worked collaboratively and used different resources; like dictionaries or books in order to write correctly. Besides, artifacts allowed me to observe and analyze, through the different drawings and writing drafts, how the students constructed meanings and expressed what they thought and felt along the writing process.

Each one of the instruments mentioned above offered the possibility to observe, analyze, describe and reflect upon different interactions, perceptions, roles and the development of activities in the third grade EFL classroom. On the other hand, as a teacher researcher, I decided to use these instruments because they allowed me to document different steps during the research process. Audio recordings were made during all the sessions, and they helped me to analyze the different interactions within each group. The recordings were complemented with field notes which contributed to enrich the observation of the writing process. On the other hand, artifacts were collected 
through all the sessions as well, and they contributed to analyze the different students' perceptions about the world, that is to say, the construction of meaning during the writing process, what they felt and what they thought. The instruments selected helped me to reflect about my own pedagogical practice and finally to answer the research questions.

\section{Findings and discussion}

Regarding the first research question, "What critical thinking skills are evidenced when project work is implemented with third grade EFL students"? two categories were established: (1) Basic critical thinking skills and (2) Emerging higher critical thinking skills when project work was implemented. From the second question, "What is the role of project work in the development of writing skills in third grade EFL learners"? These categories were identified: (1) Project work promotes peer monitoring and scaffolding in the writing process, (2) it can allow teachers to enhance students' knowledge of the L2, and (3) it facilitates the expression of feelings, likes, advice, concern, and necessities. In order to provide more organization to the text the two research questions will be analyzed separately.

Table 1. Categories and Subcategories

\begin{tabular}{|c|c|c|}
\hline Research Questions & Categories & Subcategories \\
\hline $\begin{array}{l}\text { What critical thinking skills are evidenced when project } \\
\text { work is implemented with third grade EFL students? }\end{array}$ & $\begin{array}{l}\text { 1. Basic critical thinking skills. } \\
\text {. Emerging higher critical thinking } \\
\text { skills. }\end{array}$ & $\begin{array}{l}1.1 \text { Recalling information learned in } \\
\text { both languages and explaining ideas. } \\
1.2 \text { Interpreting illustrated poems, gra- } \\
\text { phics, instructions and initial process of } \\
\text { synthesis. } \\
2.1 \text { Applying knowledge to express } \\
\text { ideas and create own texts. } \\
2.2 \text { Using previous and new knowledge } \\
\text { to establish cause - effect relationships, } \\
\text { and to structure and support the project. } \\
2.3 \text { Assessing own and each other's } \\
\text { ideas and performance. }\end{array}$ \\
\hline $\begin{array}{l}\text { What is the role of project work in the development of } \\
\text { writing skills in third grade EFL learners? }\end{array}$ & $\begin{array}{l}\text { 1. Project work promotes peer mo- } \\
\text { nitoring and scaffolding in the writing } \\
\text { process. } \\
\text { 2. Project work can allow teachers to } \\
\text { facilitate students' meaningful writing } \\
\text { process in the L2 } \\
\text {. Project work can facilitate the } \\
\text { expression of feelings, likes, advice, } \\
\text { concerns, and necessities }\end{array}$ & $\begin{array}{l}\text { 1.1 Checking together vocabulary } \\
\text { learned and using it in new contexts } \\
\text { 1.2 Making corrections in groups } \\
\text { (student-student and student-teacher). } \\
\text { 2.1 Promoting dictionary use to unders- } \\
\text { tand and write words \& expressions and } \\
\text { practicing the use of synonyms. } \\
\text { 2.2 Fostering associations \& descrip- } \\
\text { tion of images. } \\
2.3 \text { Guiding the use of pronouns to refer } \\
\text { to people \& things. }\end{array}$ \\
\hline
\end{tabular}

The first category related to the first research question refers to Basic critical thinking skills and embraces two subcategories. They show some thinking skills that constitute the foundation of critical thinking. The subcategories that emerged were: First, recalling information learned in both languages and 
explaining ideas, and second interpreting illustrated poems, graphics, instructions and initial process of synthesis.

Through the project work implementation two critical thinking skills were evidenced with the third grade students: Recalling information and explaining ideas. "Recalling" refers to the ability to evoke, remember, use memory, and repeat information learned at any moment; in other words, it involves recalling relevant knowledge from long-term memory. This can be noticed in the following excerpt:

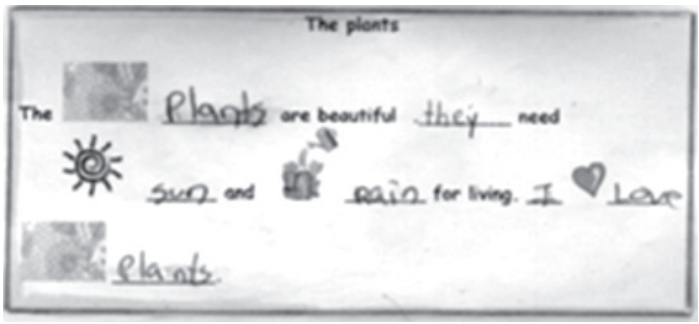

Figure 4. Artifact 1

In this excerpt, students interpreted the concepts represented by images and associated them with the written words to assign meaning to a text and complete it. The students had to observe the text and fill in the blanks with the word according to the image. They analyzed each sentence, and after this, according to the image, they wrote the appropriate word in order to build a coherent sentence. Students used some strategies such as looking up for the word in the dictionary, asking the teacher or a peer, or using vocabulary cards. This activity allowed students not only to improve the strategies mentioned and increase their vocabulary, but also to improve their writing process because they had to analyze, think, and choose the correct word in order to write a meaningful and coherent text.

The second category refers to the skills which require more complex levels of elaboration. It was called: Emerging higher critical thinking skills. Those complex levels were organized in the following subcategories: First, applying knowledge to express ideas and create own texts; second, using previous knowledge to establish cause - effect relationships, and support the project, and third, assessing own and each other's ideas and performance. This can be observed in the following excerpt:

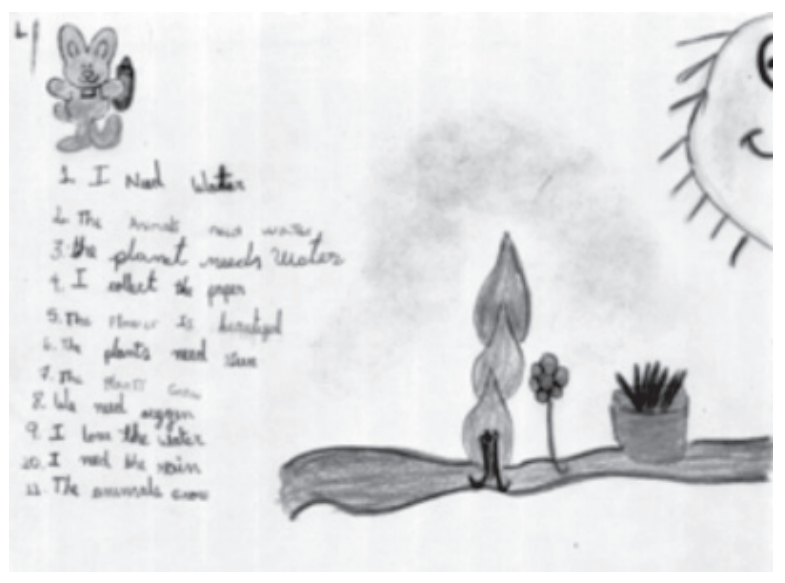

Figure 5. Artifact 2

This example referred to the student's ability to construct meaning, applying the knowledge and vocabulary previously learned in order to write new sentences, to create their own texts. This ability involved remembering the meaning of the words and at the same time writing clear sentences in order to express students' ideas, knowledge, and suggestions and to create their own texts showing the knowledge acquired and their points of view about their research topic.

According to Bloom's revised taxonomy (1990), applying implies using a concept in a new situation or an unprompted use of an abstraction. It involves transferring what was learned in the classroom into novel situations. The previous example shows how the third grade students constructed sentences about a topic they investigated, using the vocabulary learned throughout the English course and their background knowledge.

On the other hand, the following three categories are related to the second research question: First, project work promotes peer monitoring and scaffolding in the writing process; second, project work can allow teachers to facilitate students' 
meaningful writing process in the L2; and third, project work can facilitate the expression of feelings, likes, advice, concerns, and necessities.

For the first category two subcategories were established: First, checking together vocabulary learned and using it in new contexts, and second, making corrections in groups (student-student and student-teacher).

This process included the way the students worked collaboratively and used different tools to construct short sentences in English. Students discussed and helped each other throughout the different sessions in order to construct coherent and complete sentences using vocabulary learned in English. Students scaffolded by the teacher's questions, used vocabulary cards and pronouns cards in order to construct the sentences to express their ideas and share their knowledge. This can be observed in the following example:

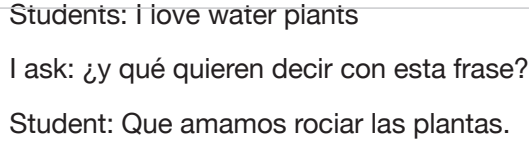

Teacher: Entonces, busquen una ficha que represente gustar; por ejemplo en la que a los niños les gusta comer helado.

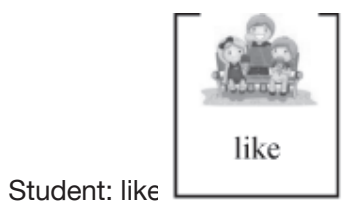

Then we say: I like to water the plants Let's repeat: I like to water the plants. Very good!

Figure 6. Field notes 1

In this part of the session students had to look up the correct word in order to construct the sentence correctly. Students used vocabulary cards as a tool to write the phrase. In this case, they could see the picture and then understand the meaning of the word and then use it in appropriate way to describe their ideas.

For the second category, namely Project work can allow teachers to facilitate students' meaningful writing process in the L2, the following subcategories were found: First, promoting dictionary use to understand and write words and expressions and practicing the use of synonyms; second, fostering associations and description of images; and third, guiding the use of pronouns to refer to people and things.

This process included the students' and teacher's participation in each one of their groups to check their writings together. In this session students were discussing the sentences they would include in their summaries in English, which were constructed in groups. These summaries were based on the readings done by the students in a previous stage.

As students were writing the sentences about water care, they were monitoring which were the best words to express their ideas and the way those words were spelled. In this sense, Dresden and Lee (2007) mention that project work provides more enriched learning opportunities. In this research, the third grade students had the opportunity to interact, negotiate meaning, work collaboratively and make corrections within the groups as can be observed in the following excerpt:

592. S1: venga ponga acá the o sea el...

593. S2: water

594. S1: no animales ... animals ... need ...

595. S3: ah... animals no salió bien... mejor con plants

596. S1: bueno, hágalo

597. S3: p,l,a,n,t,s

598. S1: plants, primero la t luego la s.

599. S3: PLANTS

600. S1: NEED

601. S3: ¿ la e?

602. S1: need... eh... water

603. S1: LISTA ... the plants need water.

Figure 7. Audio recordings 
The third category established was: Project work can facilitate the expression of feelings, likes, advice, concerns, and necessities. This category refers to the opportunity that project work offers students for writing with a purpose. They had more to say and more to write because they could express their feelings toward nature and animals, give advice, and write about their concerns. It was also a valuable opportunity for writing critically because the students were able to analyze, apply and finally, create sentences according to their interests. In the first sentence students expressed necessity: "The plants need sun and rain", in the second sentence students expressed obligation or advice: "We should feed plants with water" and in the third sentence they gave advice: "We should protect plants and animals." In this case, students could express their feelings and thoughts about the necessity of taking care of plants. The development of the project allowed the students to interact, negotiate meaning, and at the same time, improve the writing process. Along the project, students commented and discussed with their classmates and teacher about the use of words and the dictionary, and they finally wrote more coherently and with more sense than before starting the project.

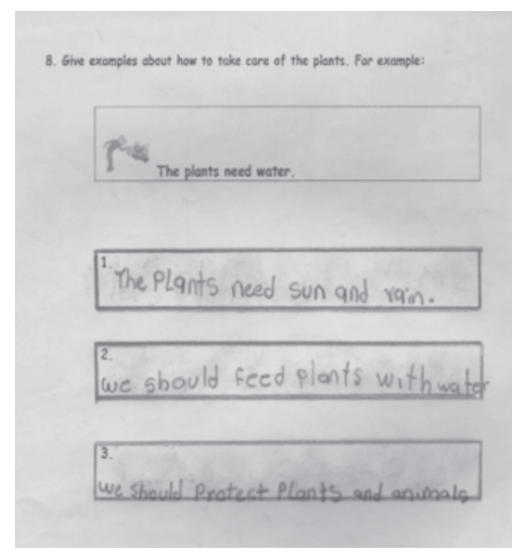

Figure 8. Artifact 3

Finally, I can state that project work motivated students during their writing process. Students had more opportunities to interact with others as well as express their feelings, thoughts, likes, and necessities. Project work facilitated and enriched the writing process in the foreign language; in fact, students learned and improved their writing through their participation, interest, motivation, and experiences. As Stoller (2000), Rodriguez (2001) and Dresden and Lee (2007) state, project work is a meaningful methodology through which not only students, but also teachers integrate life, experience, practice, and knowledge. This methodology transforms the school context into a more dynamic and participative place where students and teachers have more to say, more to learn, and more to teach.

\section{Conclusions}

For the first research question, with regard to the critical thinking skills that may be evidenced when project work is implemented, two kinds of critical thinking skills were identified. The first one refers to basic critical thinking skills, namely recalling information and explaining ideas. These basic critical thinking skills refer to the students' ability for remembering, evoking specific information, and building explanations about different phenomena. Through these basic critical thinking skills students used content previously learned and their experiences, and they basically used the memorization of aspects connected to those experiences to recall concepts and give meaning to the world that surrounds them. Guided by the teacher, students were also able to integrate that previous knowledge with the new language learned, in order to make sense out of words, concepts, and texts in the foreign language.

The second set of skills refers to the emerging higher critical thinking skills. They were: First, applying knowledge to express ideas and create own texts; second, using previous and new knowledge to establish cause-effect relationships, and to structure and support the project; and third assessing own and each other's ideas and performance.

Based on these findings, it was possible to conclude that the structure and nature of project work allowed students to start using their emerging 
critical thinking skills in the EFL classroom because it encouraged the students' interest and motivation toward the topic selected during their research process.

This interest and motivation were triggered by the kind of activities planned and developed, as well as the teacher's scaffolding of the learning process. In this sense, I found that instead of developing contents based only on memorization of words or structures, the foreign language learning process improved when more reflective, analytical and critical activities were implemented through different kinds of questions, inquiry processes and the teacher's assistance.

I can also state that questions planned as part of the pedagogical intervention allowed students to increase their participation and interaction, and at the same time they moved from lower to higher levels of critical thinking. Another important aspect worth mentioning in my research process was the exposure to and analysis of different kinds of materials such as illustrated poems, graphics, and vocabulary cards, information cards through which students could answer different kinds of questions and develop higher critical thinking skills. Those materials had two important outcomes: First, they motivated the students toward the English class and contributed to catch their attention, and second, they allowed the students to interact, comment, discuss, and improve not only their relationship, but also their writing process.

As to the second research question, which asked about the role of project work in the development of writing skills in third grade EFL learners, I could observe and document that project work motivated students during their writing process. Students had more opportunities to interact with others, express their feelings, thoughts, likes, and necessities. The data also showed that project work facilitated and enriched the foreign language writing process so that students learned and improved their writing through participation, interest, motivation, and experiences.
As Stoller (2000), Rodriguez (2001), and Dresden and Lee (2007) state, project work is a meaningful methodology through which not only students, but also the teacher integrates life, experience, practice, and knowledge. The role of project work during this research was very important because it also allowed students to improve their writing process in the foreign language as a means of their self- expression, which is remarkable especially in the IED Jose Maria Carbonell school context where the English class has an allocation of two hours a week, and students have few opportunities for practicing and learning.

In addition, I was able to understand writing as a process made of steps, which was another benefit obtained through project work. As Murray (2003) states, writing is an unfinished process that requires considering that in our classrooms "we work with language in action". That action took place when we were looking for the appropriate word, negotiating meanings of sentences for expressing our thoughts, and communicating with others constantly. I could notice that during the pedagogical intervention, when students had to write, they made corrections in groups by discussing, asking, and looking for the appropriate word to express an idea. They also built sentences together to show the content and language knowledge they were acquiring and drew images to complement their written texts, therefore, improving the foreign language writing process. They had to follow different steps and understand that writing is a process, not only a product, which requires being reflective and revising many times.

All in all, through this study it was possible to establish that project work motivated students during their writing process and provided them with more opportunities to interact with others and express their feelings, thoughts, likes and necessities. Students learned and improved their writing through participation, interest, motivation, and experiences. Additionally, project work promoted peer monitoring and scaffolding in the writing process. Taking into account that writing is an unfinished process, which 
requires being reflective and revising many times, this was a meaningful methodology through which not only students but also teacher integrated life, experience, practice, and knowledge.

Finally, this research allowed me to see and understand important aspects related to my research questions and to the kind of activities, methodologies implemented and assessment made in the English class. On the other hand, it is also important to mention the positive impact that this project had on the students and in the school context: Through project work the students enhanced their emerging critical thinking skills and their writing process; besides, interactions among classmates improved, and they saw that learning English was something useful for their lives, which fostered their confidence to write and speak in English. Finally, they became more reflective, organized and critical about what they think, what they say, and about what happens around them.

\section{References}

Baynham, M. (1995). Literacy practices: Investigating literacy in social contexts. New York, NY: Longman. Bloom's revised taxonomy. Retrieved June 5, 2011, from http://www.nwlink.com/ donclark/hrd/bloom. html.

Burns, A. (2003). Collaborative action research for English language teachers. Cambridge: Cambridge University Press.

Cuspoca, J. (2002). Project work in early literacy in an EFL context. (Thesis, Master Program in Applied Linguistics for the Teaching of English as a Foreign Language). Bogotá: Universidad Distrital Francisco José de Caldas.

Davis-Seaver, J., \& Davis, J. (2000). Critical thinking in young children. Canada: The Edwin Mellen Press.

Dresden, J., \& Lee, K. (2007). The effects of project work in a first-grade classroom: A little goes a long way. Retrieved July 24, 2011 from http://ecrp.uiuc.edu/ v9n1/dresden.html.

Freeman, D. (1998). Doing teacher research: From inquiry to understanding. Boston, MA: Heinle \& Heinle Publishers.
Harris, J., \& Katz, L. (2010).Young investigators: The project approach in the early years. Washington: Columbia University.

Hyland, K. (2009). Teaching and researching writing (2a ed.). London: Longman.

Lillis, T. M. (2001). Student writing: Access, regulation, desire. New York, NY: Routledge.

Martinez, E. (2007). Fostering actions of competence broadening higher order thinking skills as a basis for standardized test-taking. How: A Colombian journal for teachers of English, 14, 27-57.

Merriam, S. (1998). Qualitative research and case study applications in education. San Francisco: JosseyBass.

Moore, B., \& Stanley, T. (2009). Critical thinking and formative assessments: Increasing the rigor in your classroom. Larchmont, NY: Eye of education.

Murray, D. (2003). Teach writing as a process not product. Retrieved October 25, 2011, from http://www. willamette.edu/gse/owp/docs/TeachWritingasaProcessNotProduct.pdf.

Patton, M. (2002). Qualitative research \& evaluation methods. Retrieved September 14, 2011, from http:// es.scribd.com/doc/44478053/Patton-2002-Qualitative-Research-and-Evaluation-Methods-3e.

Paul, R., \& Elder, L. (2005). The miniature guide to critical thinking concepts and tools. Dillon Beach CA: Foundation for Critical Thinking.

Ramirez ,L. Comunicación y Discurso. La perspectiva polifónica en los discursos literario, cotidiano y científico. Bogotá, Colombia: Editorial Magisterio.

Richards, J., \& Renandya, W. (2002). Methodology in language teaching: An anthology of current practice. New York: Cambridge University Press.

Rinnert, C., \& Kobayashi, H. (2009).Writing in foreign language contexts. Learning, teaching and research. Canada.

Rodríguez, M. (2001). Antología de proyectos pedagógicos. Cuaderno de trabajo № 2. Bogotá: Universidad Distrital Francisco José de Caldas.

Ruiz, N. (2003). Kidwatching and the development of children as writers. Profile 4, 52-57.

Silva, T. (1993). Toward an understanding of the distinct nature of L2 writing: The ESL research and its implications. TESOL Quarterly, 27, 657-677. 
Stoller, F. (2000). Project Work: A means to promote language and content. New York: Cambridge: University Press.

Wallace, M. (2006). Action research for language teachers. Cambridge: Cambridge University Press.
White, R., \& Arndt, V. (1991). Process Writing. London: Longman. Retrieved August 22, 2011 from http:// www.buowl.boun.edu.tr/teachers/PROCESS\%20 WRITING.htm.

THE AUTHOR

SANDRA DOLORES RUIZ NIÑO is an elementary school teacher. She has worked in Ciudad Bolivar and San Cristobal. Nowadays, she works at Colegio José Maria Carbonell. Sandra graduated in Spanish and English studies from the Universidad Pedagógica in 1999. In addition, she has a Master in The Teaching of Foreign Languages from the same university, in 2012. 